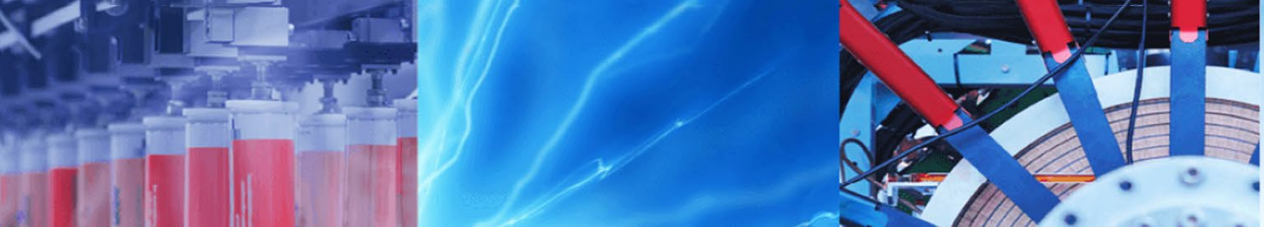

Research Article

\title{
Exploring malted barley waste for fungi producing surface active proteins like hydrophobins
}

\author{
Shraddha S. Kulkarni ${ }^{1}$ Sanjay N. Nene ${ }^{2} \cdot$ Kalpana S. Joshi ${ }^{3}$
}

Received: 18 April 2020 / Accepted: 13 October 2020 / Published online: 24 October 2020

(c) Springer Nature Switzerland AG 2020

\begin{abstract}
Malted barley waste is a rich source of different fungi. Hydrophobin like surface active proteins can be isolated from these fungal species and can be studied for industrial applications. In this study total 50 fungal strains were isolated from malt waste and screened for production of hydrophobin like protein (HYD-LP). Fungi producing highly hydrophobic spores were selected for fermentative growth. Ten such strains have shown good foam stability with half decay time more than foam of $0.1 \%$ SDS. Fungal strain S7-5 (Penicillium species close to $P$. islandicum) was selected for isolation of HYD-LPs which had lowered the surface tension of fermentation media to $31.046 \mathrm{mN} / \mathrm{m}$ with high half decay time of foam and good emulsification capacity. SDS-insoluble HYD-LP was purified using trifluroacetic acid. SDS-PAGE confirmed presence of low molecular weight protein $(15 \mathrm{kDa}$ ) isolated from spore walls and fermentation broth. This protein was partially characterized as HYD-LP by performing RP-HPLC and studying its amphipathic nature as it has made low contact angle with Teflon surface. It also formed stable layer on Teflon surface and spore wall HYD-LP decreased hydrophobicity of Teflon by lowering contact angle (CA) of water by $21.63 \%$ and HYD-LP isolated from fermentation broth lowered water CA by $37.62 \%$. This study is first to report the bio prospecting of fungi isolated from malted barley waste for biosurfactant characteristics and subsequent isolation of HYD-LP from strain close to Penicllium islandicum.
\end{abstract}

Keywords Malted barley waste · Foam stability - Surface tension . Penicillium species close to P. islandicum . Hydrophobins

\section{Introduction}

Gushing in beer is caused by fungi present in the brewing cereals. Gushing is spontaneous over foaming of carbonated beverages immediately on opening of container. Several authors have proposed that fungal infested brewing malt is responsible for primary gushing in beers specifically Fusarium species [1-3]. Genera like Penicillium, Aspergillus, Nigrospora and Stemphylium are also investigated for producing gushing factors [4]. Gushing factors are reported to be surface active proteins, like hydrophobins. Recently fungi infecting wine grapes were isolated and studied for secretion of surface active proteins which were responsible for gushing in wine [5].

Hydrophobins are cysteine rich amphipathic surface active proteins produced by fungi. Due to their amphipathic nature they show surfactant properties at the cell wall-air interface by lowering the surface tension of the medium [6]. They were discovered as molecules helping fungi to escape excess water levels and grow in natural habitat. Along with this they play major role in attachment of fungi to hydrophobic surfaces [7], pathogenesis, endophytic association with plants etc. [8]. Depending upon formation of soluble or insoluble polymers called as

\footnotetext{
Kalpana S. Joshi, kalpanajoshi1788@gmail.com; Shraddha S. Kulkarni, shraddhautpat@gmail.com; Sanjay N. Nene, sanjay.nene@gmail.com | ${ }^{1}$ Department of Technology, Savitribai Phule Pune University, Pune 411041, India. ${ }^{2}$ Innovation Biologicals Private Limited, 100 NCL Innovation Park, Dr. Homi Bhabha Road, Pashan, Pune 411 008, India. ${ }^{3}$ Department of Biotechnology, Sinhgad College of Engineering, Affiliated to Savitribai Phule Pune University, Pune 411041, India.
} 
rodlets, hydrophobins are divided in to two classes, class I and class II. Due to unique arrangements of hydrophobic and hydrophilic amino acids; hydrophobins are appraised as an industrially important molecule with applications in drug delivery, antifouling agent for medical devices, Food foams, and other biotechnological applications $[9,10]$.

Efforts have been made for isolation and production of hydrophobins from fungi originating from diverse environment [11-15]. Except Fusarium species, no other fungal species has been studied for isolation of hydrophobins from malted barley. Study of Fusarium species was mainly focused on negative impact of hydrophobins on quality of beer due to gushing effect [1-3].

Considering the importance of hydrophobins to the industry, the present study was aimed to isolate, screen and evaluate malted barley associated fungi for production of hydrophobin/hydrophobin like proteins. Samples for isolation of fungi were collected from 8 stages of malting. These samples contained dust and rejected barley grains after each stage of malting. Isolation of fungi was carried out using dust and barley grains. Isolated strains from these sources can be considered as a mixture of fungi present on barley since their harvest and some fungi infested barley during malting process [3]. Surfactant properties of fermentation broth produced by different fungi were evaluated. Simple methods like foam stability, oil spread assay, surface tension measurement and emulsification index have been used to identify potential surface active protein producers. These strains were further used for isolation of surface active proteins like hydrophobins. As Hydrophobins are low molecular weight proteins, molecular weights of these isolated proteins were confirmed by SDS-PAGE. Amphipathic nature of proteins has been determined by RP-HPLC, contact angle measurement of water on Teflon surface and by surface wettability study.

\section{Materials and methods}

\subsection{Isolation of fungi from malted barley waste samples}

Eight malted barley waste samples were collected from Barmalt Malting India Pvt.Ltd., Gurgaon, Haryana, India and numbered as $\mathrm{S} 1$ to $\mathrm{S} 8$. The malted barley waste samples were collected aseptically and transferred to laboratory in sterile polythene bags within $48 \mathrm{~h}$ of sample collection. Isolation of fungi was carried out by sprinkling technique [16] and serial dilution followed by spread plate on Potato Dextrose Agar (PDA, Hi Media) incubated at room temperature for 5 days. Isolated colonies were picked up and sub cultured on PDA to obtain pure cultures. Fungal isolates were stored using PDA slants.
Selected strains were submitted to National Fungal Culture Collection of India (NFCCI), Agharkar Research Institute Pune for morphological identification by experts.

\subsection{Relative hydrophobicity study of isolated fungi}

Relative Hydrophobicity of fungal species was determined by examining surface hydrophobicity of spores using phase distribution assay. Fungal spore suspension was collected in saline containing $0.01 \%$ Tween 80 (Loba Chemie) and centrifuged at $5000 \mathrm{rpm}$ for $10 \mathrm{~min}$. The pellet was suspended in Tris base of pH 5 (SRL). Cell concentration was adjusted to an absorbance of about 0.6 at $600 \mathrm{~nm}$. $4 \mathrm{ml}$ of suspension was taken in to a glass test tube and an equivalent volume of toluene (hydrophobic phase) was added. Each tube was vigorously vortexed for $10 \mathrm{~s}$ and then left for 30 min during which two phases were separated from each other. Distribution of spores in toluene and water phase was measured by recording optical density of aqueous phase and results were expressed as proportion of cells excluded from aqueous phase [17].

\subsection{Biosurfactant characterization of isolated fungal strains}

\subsubsection{Foam production and stability study}

Potato Dextrose Broth (PDB, Hi Media) was used as a growth medium for the fermentative growth of fungi. Fermentation was carried out in $250 \mathrm{ml}$ flask containing $100 \mathrm{ml}$ of PDB for 3-5 days. pH of the medium was adjusted to 5.5. Each flask was inoculated with $2 \times 10^{7}$ spores $/ \mathrm{ml}$ and incubated at room temperature. After 5 days of fermentation mycelia were separated from fermentation broth by filtration. Foam was produced in fermentation broth using wearing blender at low speed for $5 \mathrm{~min}$. In bulk scale experiment $0.1 \%$ Sodium dodecyl sulphate (SDS, Hi-media) (CMC: $0.23 \mathrm{~g} / \mathrm{L}$ ) was used as a positive control to check and compare stability of foam produced by different fungal species [18]. Glass Beaker of $500 \mathrm{ml}$ was used for blending of collected fermentation broth. Diameter and height of beaker was $7.76 \mathrm{~cm}$ and $11.5 \mathrm{~cm}$ respectively. The foam height attained in the beaker was recorded after blending of cell free fermentation broth for $5 \mathrm{~min}$. Height of foam was monitored approximately for $4 \mathrm{~h}$. Change in foam height was monitored and recorded for every $10 \mathrm{~min}$. Half decay time profile of the foam was measure [19]. This experiment was performed in duplicates to ensure repeatability of the results. Protein content of fermentation broth and the separated foam was estimated using Bradford protein assay [20]. 


\subsubsection{Surface tension measurement}

Surface tension of fermentation broth and foam of most stable foam producing fungal species was checked using Surface Tensiometer with Wilhelmy plate technique using a digital automated Easy Dyne Tensiometer [21] (Model DCAT11, Data Physics). Surface tension was measured at room temperature against a standard deionized water and Potato dextrose broth. In a similar way to foam stability experiment, foam was produced in fermentation broth using warring blender for 5 min and foam was immediately separated from liquid phase and collected in falcon tubes. These collected foam samples were allowed to collapse and used for measurement of surface tension. These foam samples were further used for emulsification assay and oil displacement studies.

\subsubsection{Emulsification assay}

Modified emulsification assay was performed according to method described by Ma et al. [22-24]. Hexane and Olive oil was used as an oil phase for emulsification experiment. Emulsion was formed by mixing collected foam with hexane/Olive oil in equal volumes. This mixture was ultra-sonicated (Vibra Cell, Sonics, Inkarp) for 5 min at amplitude of $50 \%$ and kept at room temperature for $24 \mathrm{~h}$. To evaluate the emulsification capacity of the samples the height of emulsified layer was monitored for 2-3 days.

\subsubsection{Oil spread assay}

Oil spread technique was carried out using method described by Morikova et al. [25] and Youssef et al. [26]. $30 \mathrm{ml}$ of distilled water was added to the Petri dish followed by addition of $100 \mu \mathrm{l}$ of crude oil on to the water surface. A foam sample from the respective species $(10 \mu \mathrm{l})$ was overlaid on to the oil. The diameter of clear zone on oil layer was measured.

\subsection{Extraction of class I and class II HYD-LPs from selected fungi}

Isolation of SDS-insoluble class I HYD-LPs from spores of strain S7-5(Penicillium species close to P. islandicum) was performed according to protocol of Wessels et al. [27] and de Vries et al. [28] with slight modification. Spores grown on PDA medium were collected from petri plates and mixed with $2 \% \mathrm{SDS}(\mathrm{Hi}$ media)in $100 \mathrm{mM}$ Tris- $\mathrm{HCl}(\mathrm{Hi}-$ media) buffer of $\mathrm{pH} 8$ followed by heating this mixture at $90^{\circ} \mathrm{C}$; mixture was centrifuged at $3000 \times g$ for $20 \mathrm{~min}$. Pellet was washed six times with water and suspended in $1 \mathrm{ml}$ concentrated TFA (SRL) and kept in sonication bath by maintaining temperature of about $10{ }^{\circ} \mathrm{C}$ for
$15 \mathrm{~min}$ followed by centrifugation at $8000 \times \mathrm{g}$ for $20 \mathrm{~min}$ and supernatant was collected. To remove TFA sample was dried in stream of air. Dried samples were stored and dissolved in $100 \mathrm{mM}$ Tris- $\mathrm{HCl}$ buffer for further work. To isolate surface active HYD-LPs from mycelia protocol of S. Longobardi was followed [29]. Fungal strain S7-5 was grown for 5 days in conical flasks containing Potato Dextrose Broth (PDB) of pH 5.5 at $28^{\circ} \mathrm{C}$. Mycelia were separated from fermentation broth after 5 days growth. Mycelia were treated twice with $2 \%$ SDS in boiling water bath for $10 \mathrm{~min}$ and washed several times with water followed by $60 \%$ ethanol. To dissociate and extract proteins, residue was freeze dried and dissolved in TFA in a sonication bath for $10 \mathrm{~min}$. Supernatant was dried in stream of air and dissolved in $60 \%$ ethanol and centrifuged $(10 \mathrm{~min}$ at $3200 \times g$ ) followed by three times extraction with chloroform-methanol (2:1 V/V). Precipitate was dissolved in TFA by repeating air drying and dissolving in $60 \%$ ethanol. $\mathrm{pH}$ of the protein sample was adjusted to 7 using liquid ammonia. Proteins were finally induced to aggregate at $80^{\circ} \mathrm{C}$ and obtained precipitate was finally treated with TFA as described above and redissolved in $100 \mathrm{mM}$ Tris- $\mathrm{HCl}$ buffer for analysis. Isolation of class II hydrophobin was performed according to method described by [30] with some modifications [31]. Spores of S7-5 strain were grown on PDA plated for 5-7 days and mycelia collected from fermentation broth after 5 days growth in PDB of pH5.5 at $28^{\circ} \mathrm{C}$ was collected and lyophilized. Lyophilized fungal biomass treated with $20 \mathrm{ml} 60 \%$ ethanol $/ 100 \mathrm{mg}$ of fungal spore biomass in sonication bath for $10 \mathrm{~min}$. Supernatant was collected by centrifugation at $5000 \times g$ for $15 \mathrm{~min}$. This supernatant was freeze dried and dissolved $100 \mathrm{mM}$ Tris-HCl buffer for further analysis.

In comparison to mycelia, isolation of surface active HYD-LPs secreted into fermentation broth was simple. Foam was produced in separated fermentation broth using wearing blender for 10-13 min followed by centrifugation $20 \mathrm{~min}$ at $4000 \times \mathrm{g}$ and freeze dried. To purify class I HYD-LP dried sample was treated with TFA for $2 \mathrm{~h}$ at $4{ }^{\circ} \mathrm{C}$ and sonicated for $30 \mathrm{~min}$ in bath sonicator. After centrifugation at $3200 \times \mathrm{g}$ for $20 \mathrm{~min}$ supernatant was dried in air and protein sample was dissolved in $100 \mathrm{mM}$ Tris- $\mathrm{HCl}$ buffer for analysis. Class II HYD-LP were extracted by dissolving pellet of foam recovered after centrifugation with $60 \%$ ethanol [31]

\subsubsection{SDS-PAGE analysis of purified HYD-LPs}

Total Protein concentration of fermentation broth, collected foam and purified samples was determined using Bradford assay [20]. Purified SDS-insoluble HYD-LPs were further analyzed on discontinuous SDS-PAGE system as per the method described by Laemmli [32]. The protein 
samples were mixed with sample buffer containing $60 \mathrm{mM}$ Tris- $\mathrm{HCl}(\mathrm{pH} 6.8), 25 \%$ glycerol (v/w), 2\% (w/v) SDS, $14.4 \mathrm{mM}$ 2-mercaptoethanol, and $0.1 \%$ bromophenol blue and boiled for $5 \mathrm{~min}$ before loading on the Tris-glycine gels ( $10 \%$ separating gel and $5 \%$ stacking gel). At the start of the run voltage was maintained at $40 \mathrm{~V}$ for half an hour and then increased to $60 \mathrm{~V}$ and continued for $2 \mathrm{~h}$ using mini vertical electrophoresis unit (Orange, VMR0007). After completing the run gel was stained overnight with $1 \%$ Coomassie Brilliant Blue R-250 (Hi Media) and destained completely to visualize the bands using destaining solution (10\% methanol and 10\% glacial acetic acid).

\subsubsection{Reversed phase high performance liquid chromatography (RP-HPLC) analysis of HYD-LPs}

To partially characterize amphipathic nature of the isolated proteins HPLC (Shimadzu LC 2010HT) analysis was performed using reverse phase $\mathrm{C} 18$ column designed for protein estimation. Composition of Solvent A of the mobile phase was $0.1 \%$ Trifluroacetic acid, in MilliQ HPLC grade water, and of solvent $B$ was $0.1 \%$ Trifluroacetic acid in Acetonitrile. A linear gradient of solvent $B$ was established from 0 to $90 \%$ in $40 \mathrm{~min}$ at a flow rate of $0.8 \mathrm{ml} / \mathrm{min}$. Absorbance of protein was measured at $214 \mathrm{~nm}$ [33].

\subsubsection{Contact angle measurements}

To verify surface activity of extracted proteins contact angle measurement tests were performed.

a) Contact Angle determination of proteins:

Hydrophobic surface of polytetrafluoroethylene (Teflon) was prepared by coating glass slide with Teflon material available in local market. This surface was sterilized using ethanol and air dried. $10 \mu \mathrm{l}$ of aqueous sample containing $50 \mu \mathrm{g} / \mathrm{ml}$ of HYD-LP was pipetted on to the surface of $18.75 \mathrm{~cm}^{2}$ and stabilized for $1 \mathrm{~min}$. Deionized water and 2\% SDS were used as negative and positive controls respectively. Images of drops were captured in Digital Camera (Sony SLT alpha 58). Contact angles were measured by low-bond axisymmetric drop shape analysis (LB-ASDSA) using Image J plugin software [34-36]. Contact angle for each sample was calculated in duplicates by placing drops on three different points of the Teflon surface.

b) Wetting ability Determination of isolated Surface active proteins

Glass Slides of $18.75 \mathrm{~cm}^{2}$ surface area were coated with Teflon and used as hydrophobic surface. Surface was sterilized by washing three times with ethanol followed by rinsing three times with water and air dried for $12 \mathrm{~h}$.
$100 \mu \mathrm{l}$ of the extracted proteins $\left(50 \mu \mathrm{g}\right.$ protein $\left.\mathrm{ml}^{-1}\right)$ was applied on Teflon surface and dried for $16 \mathrm{~h}$. Each slide was washed by $2 \%$ SDS at $90{ }^{\circ} \mathrm{C}$ and rinsed three times with water followed by drying for $16 \mathrm{~h}$. Control slides were prepared identically without applying protein sample. Surface hydrophobicity of modified surface was measured in duplicates by measuring contact angle of water drop $(10 \mu \mathrm{l})$ placed on three different points using digital camera (Sony SLT alpha 58) and analyzed using Image J software with LB-ASDSA plugin [34-36].

\section{Results and discussion}

\subsection{Foam production and stability}

Malted Barley waste samples were explored for isolation of different fungi. Fifty fungal strains were isolated from samples collected at eight stages of malting (S1 to S8). Screening strategy designed for selection of HYD-LP producing fungi is depicted in Fig. 1. Hydrophobins/ hydrophobin like proteins (HYD-LPs) are present on spore walls of fungi and make the spores hydrophobic in nature by covering polysaccharides present in the wall [37-39]. In consideration with this property spores of these fifty strains were examined for surface hydrophobicity using phase distribution assay. In this assay spores were allowed to distribute in between hydrophilic (aqueous) and hydrophobic (toluene) phase. Spores of fungal strains showing strong surface hydrophobicity distributed more in toluene phase and exhibited large hydrophobicity indices. Out of the fifty strains, fifteen strains have shown hydrophobicity indices above $70 \%$ (Table 1).

To check foam stability strains were grown in shake flask cultures using PDB for 5-7 days. Fermentation broth was separated from mycelia by filtration. Collected fermentation broth of each strain was studied for stable foam formation. Stabilization of foams and emulsions is the exclusive property of hydrophobins [21, 40-43]. Stable foam formed was considered as indicator of the secretion of HYD-LPs in fermentation medium by fungi. Foam stability was measured by quantitative method of calculating half decay time profile of foam [19]. The half decay time is the time taken to reach half of the initial height of the foam. Foam produced using warring blender in $1000 \mathrm{ml}$ glass beaker for $5 \mathrm{~min}$ was monitored for change in a height of foam and the change was recorded after every $10 \mathrm{~min}$. Height measurement was continued for $4 \mathrm{~h}$. Height attained immediately after 5 min of blending was recorded as initial height of foam $\left(\mathrm{H}_{0}\right)$. Foam produced by each strain reached half of its initial height at a characteristic time interval. Half decay time was calculated by ratio of time taken to reach half height $[\mathrm{H}]$ to its initial height 


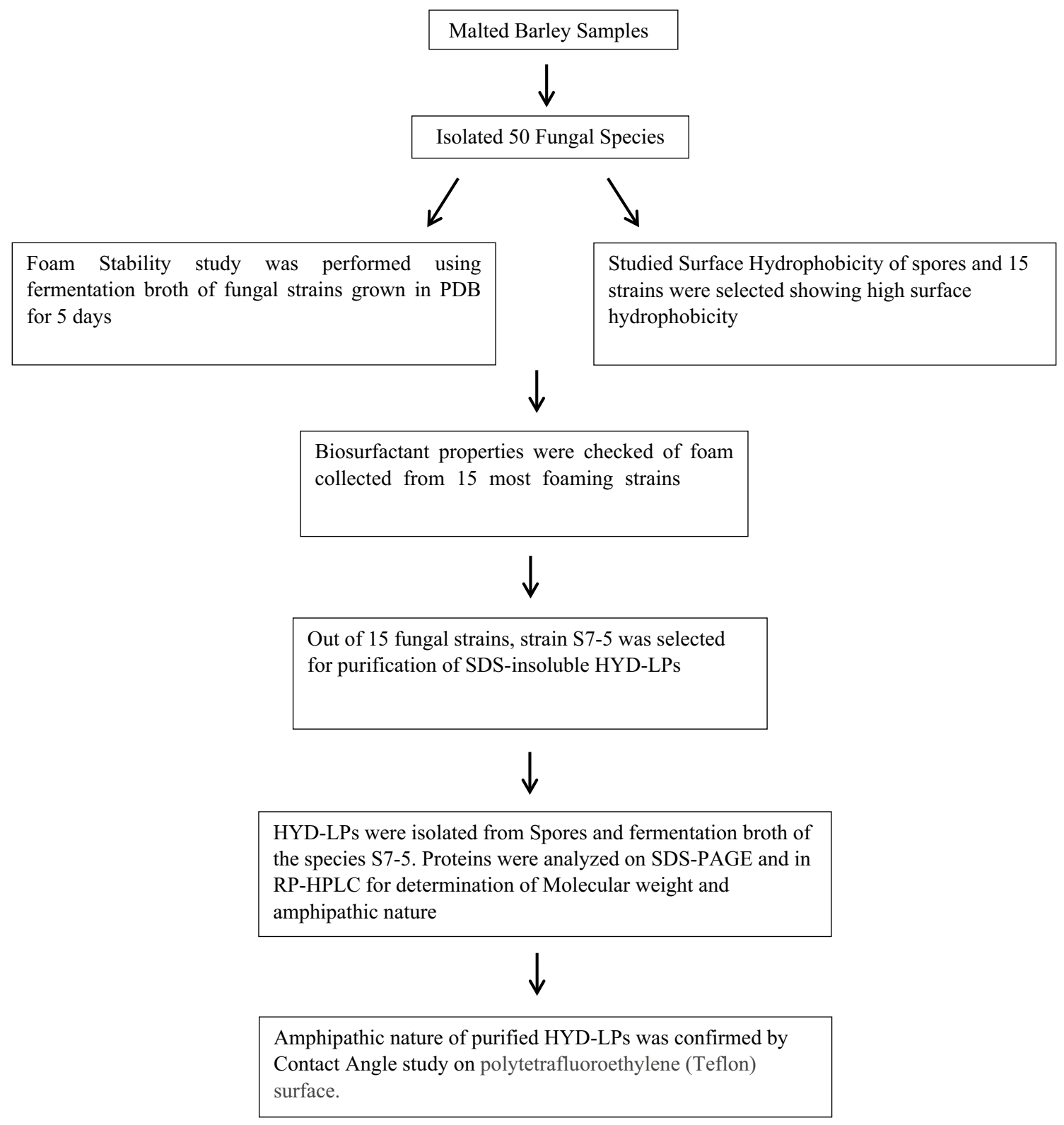

Fig. 1 Screening Strategy designed for isolation of HYD-LP producer fungi

$\left[\mathrm{H}_{0}\right]$ for foam produced by each strain and curves were presented from Fig. $2 a-f$. SDS (0.1\%) was used as a positive control for comparison of half decay time profile of all the foam producing strains. It was the criterion to determine foam stability; such that higher the half decay time more stable the foam and vice versa. It was studied that stability of foam depends upon presence and concentration of HYD-LPs. Class II hydrophobins HFBI and HFBII purified from fungi Trichoderma reesei stabilized foam for longer time (12-17 days). Mechanism behind this stability lies in coverage of bubbles with layer of hydrophobins preventing coalescence of bubbles and in turn disproportion of foam [41, 42]. Foam formation by fungi is commonly observed during fermentative growth in aerated bioreactors. Study suggested that deletion of hydrophobin genes from fungal species lead to minimal foaming during fermentation process. Genes of HFBI and HFBll deleted from $T$. reesei resulted in developing less foam during fermentation process due to absence of these proteins in fermentation broth in comparison to wild type strain [44].

Half decay time profile of foam produced by strains isolated and selected from S1 malt waste samples is presented in Fig. 2a. 16 fungal strains were isolated from S1 sample, out of which only two strains were found to produce stable foam with good spore surface hydrophobicity. In comparison to $0.1 \%$ SDS (with half decay time of 
Table 1 Detection of Biosurfactant activity of fungi using selected methods

\begin{tabular}{|c|c|c|c|c|c|c|c|}
\hline \multirow{2}{*}{$\begin{array}{l}\text { Strain } \\
\text { nomen- } \\
\text { cla-ture }\end{array}$} & \multirow[t]{2}{*}{ Strain identification } & \multirow{2}{*}{$\begin{array}{l}\text { Protein content } \\
\text { of foam }(\mathrm{mg} / \\
\mathrm{ml})\end{array}$} & \multirow{2}{*}{$\begin{array}{l}\text { Oil spread } \\
\text { zone }(\mathrm{mm})\end{array}$} & \multirow[t]{2}{*}{ Surface tension $(\mathrm{mN} / \mathrm{m}) \mathrm{a}$} & \multirow{2}{*}{$\begin{array}{l}\text { Hydropho- } \\
\text { bicity index } \\
\text { (\%) } \\
\text { (\%)pH } 5\end{array}$} & \multicolumn{2}{|c|}{ Emulsification index } \\
\hline & & & & & & Olive oil & Hexane \\
\hline S1-7 & Aspergillus fumigatus gr & $3.21 \pm 0.02$ & 6 & $36.830 \pm 1.61$ & $80 \pm 1.41$ & $83.45 \pm 3.85$ & $54.23 \pm 3.49$ \\
\hline $\mathrm{S} 1-8$ & Aspergillus flavus gr & $1.53 \pm 0.06$ & 5.6 & $41.770 \pm 0.38$ & $88.18 \pm 1.35$ & $63.24 \pm 1.39$ & $10.2 \pm 1.48$ \\
\hline S2-1 & Aspergillus versicolor gr & $0.916 \pm 0.14$ & 11 & $47.630 \pm 2.91$ & $95.64 \pm 2.33$ & $75 \pm 2.12$ & $37.5 \pm 5.37$ \\
\hline S2-2 & Aspergillus glaucus gr & $0.691 \pm 0.01$ & 3 & $43.520 \pm 0.52$ & $70.66 \pm 1.19$ & $63.15 \pm 1.48$ & $15.78 \pm 1.78$ \\
\hline S2-4 & $\begin{array}{l}\text { Aspergillus flavus var. } \\
\text { oryzae }\end{array}$ & $0.4615 \pm 0.04$ & 11 & $42.323 \pm 0.77$ & $69.52 \pm 0.58$ & $61.12 \pm 3.39$ & $5.55 \pm 1.45$ \\
\hline S2-7 & Aspergillus versicolor gr & $1.2145 \pm 0.15$ & 4 & $49.231 \pm 1.91$ & $98.65 \pm 1.59$ & $75 \pm 4.40$ & $43.75 \pm 1.66$ \\
\hline S2-8 & Aspergillus candidus gr & $2.3135 \pm 0.02$ & 2 & $48.923 \pm 2.52$ & $97 \pm 1.27$ & $58.82 \pm 3.25$ & $29.41 \pm 1.83$ \\
\hline S2-9 & Aspergillus flavus Link & $3.3965 \pm 0.05$ & 3 & $46.596 \pm 1.59$ & $95.68 \pm 0.39$ & $55.55 \pm 1.63$ & $44.44 \pm 4$ \\
\hline S5-7 & Aspergillus flavus Link & $0.455 \pm 0.08$ & 8 & $46.996 \pm 1.34$ & $74 \pm 0.57$ & $76.47 \pm 0.81$ & $33.33 \pm 2.21$ \\
\hline S5-9 & Aspergillus terreus gr & $1.696 \pm 0.01$ & 2 & $48.752 \pm 0.16$ & $71.5 \pm 1.70$ & $78.57 \pm 1.16$ & $31.25 \pm 0.95$ \\
\hline S7-5 & $\begin{array}{l}\text { Penicillium sp. close to } \\
\text { Penicillium islandicum }\end{array}$ & $0.7235 \pm 0.03$ & 9 & $31.046 \pm 0.75$ & $84.71 \pm 1.06$ & $81.25 \pm 2.04$ & $56.25 \pm 3.50$ \\
\hline S8-2 & - & $3.74 \pm 0.99$ & 4.5 & $47.630 \pm 0.02$ & $97.75 \pm 0.86$ & $57.87 \pm 1.73$ & $15.3 \pm 6.36$ \\
\hline S8-4 & Aspergillus flavus Link & $1.82 \pm 0.04$ & 18.2 & $42.452 \pm 2.58$ & $98.34 \pm 0.78$ & $74.56 \pm 1.27$ & $23.45 \pm 3.08$ \\
\hline S8-5 & - & $4.32 \pm 0.46$ & 9.2 & $43.520 \pm 7.20$ & $99.2 \pm 0.48$ & $73.24 \pm 0.79$ & $922.12 \pm 3.83$ \\
\hline S8-6 & Aspergillus flavus Link & $2.01 \pm 0.23$ & 5.3 & $37.494 \pm 5.08$ & $79 \pm 0.54$ & $70.34 \pm 1.26$ & $18.74 \pm 3.78$ \\
\hline
\end{tabular}

Bold indicates three promising candidates (Apergillus fumigatus gr., Penicillium sp. close to Penicillium islandicum, Aspergillus flavus Link) screened after variuos studies performed and results documented. These three strains were the best strains isolated and studied out of 15 selected fungi for isolation of Hydrophobin like proteins (HYD-LPs)

${ }^{a}$ Surface tension of controls: water-71.395 $\pm 0.596 \mathrm{mN} / \mathrm{m}$; PDB medium-58.914 $\pm 0.1 \mathrm{mN} / \mathrm{m}$

$80 \mathrm{~min}$ ) both the strains S1-7 and S1-8 have shown less half decay time of $60 \mathrm{~min}$. Figure 2a clearly showed the foam collapse pattern of both the species overlapping with SDS. It indicated that foam produced by these two species was merely stable.

Comparison of half decay time of strains selected from S2 sample with SDS is represented in Fig. 2b (S2-1, S2-2 and S2-4) and 2c (S2-7, S2-8 and S2-9). Out of 12 isolated strains from S-2 sample 6 have been selected for further studies on the basis of stable foam formation and good surface hydrophobicity of spores. Except S2-8 all the remaining strains have shown higher half decay time than SDS. According to information presented in Table 1 correlation between hydrophobicity indices and foam stability was not clearly found in case of all the species from S2 sample. Strain S2-4 has shown highest half decay time of $200 \mathrm{~min}$ in a group but exhibited less spore surface hydrophobicity of $69 \%$ in comparison to other members strains.

Figure $2 \mathrm{~d}$ compiles half decay time profile of foam produced by strains isolated from S5 sample. Foam produced by S5-9 strain was extremely stable and half decay time was not attained by the foam in span of measurement time of $4 \mathrm{~h}$. This foam was found stable for almost $8 \mathrm{~h}$ without further change in height of foam. Hydrophobicity index of spores of S5-9 was good (71.5\%) but not strong like other strains (Table1). Stability pattern of foam of S5-7 was found matching with foam of positive control $0.1 \%$ SDS. Five strains were isolated from S7 sample but only one was found producing good amount of foam which was stable for more than $4 \mathrm{~h}$ (presented in Fig. 2e). Half decay time of foam was highest (200 min). Spores of this strain has also exhibited high hydrophobicity index of (84.71\%). Out of 7 isolated strains from $\mathrm{S} 8$ barley waste sample, 4 strains have shown good foam stability (Fig. 2f). Except S8-6 (20 min) all remaining strains have shown high foam stability than SDS. Correlation could be established in between foam stability and surface hydrophobicity of spores of these strains. Spores of S8-2, S8-4 and S8-5 were most hydrophobic in nature while spores of S8-6 were found less hydrophobic in comparison to other strains of the group.

The overall comparison of half decay time profile of all the fifteen selected strains with SDS is shown in Fig. $2 \mathrm{~g}$. Out of 15 studied strains 10 were found to produce more stable foam than SDS with half decay time of more than $80 \mathrm{~min}$. In these 10 strains, S2-4, S5-9, S7-5 and S8-4 were the most stable foam producing strains with half decay time of 200 min or more. It was observed that there could be hardly any association between foam stability and surface hydrophobicity of spores of all these strains. Though 

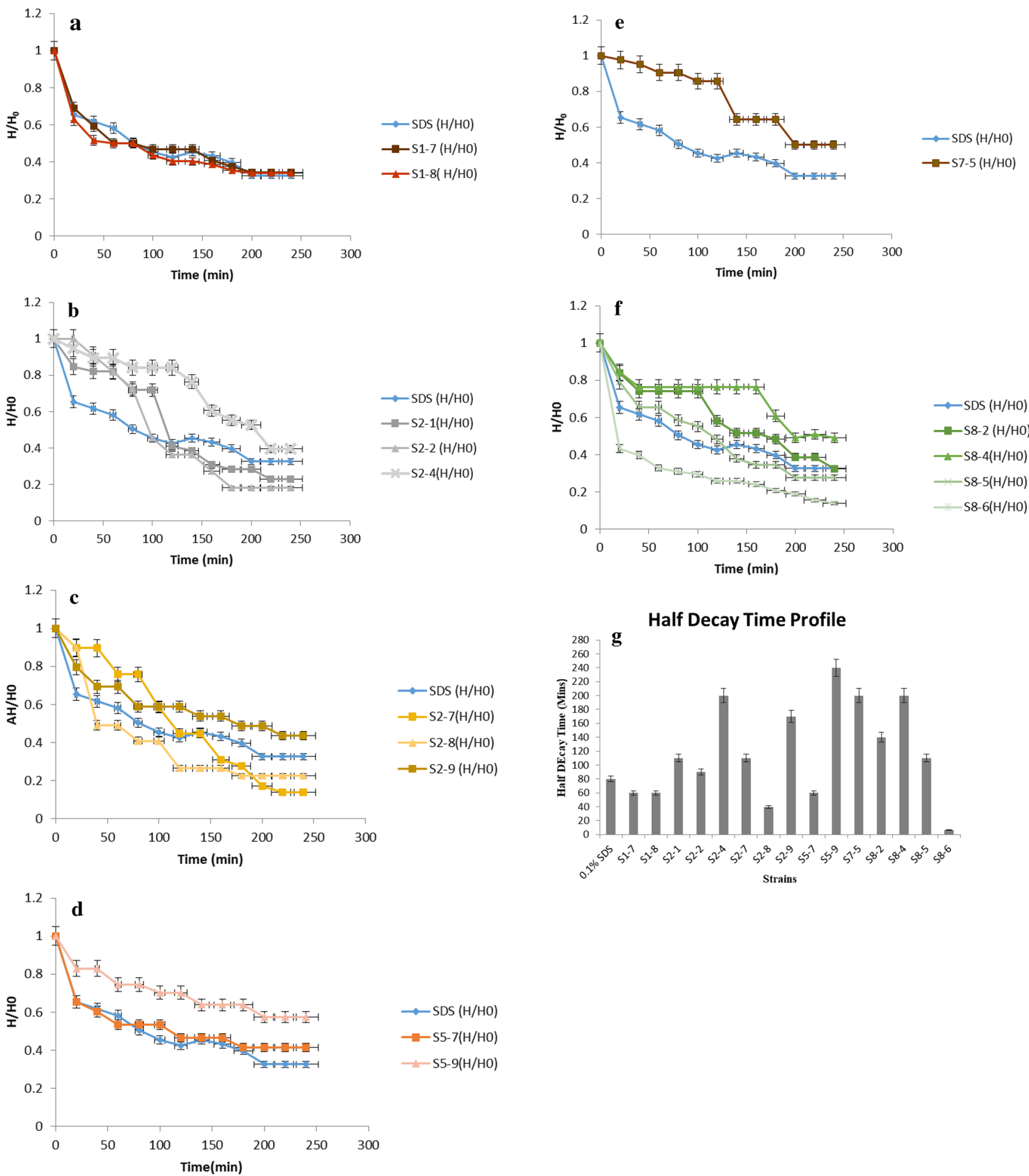

Fig. 2 a Foam half decay time profile of fungi isolated from S1 samples, b foam half decay time profile of fungi isolated from S2 samples, c foam half decay time profile of fungi isolated from S2 samples, $\mathbf{d}$ foam half decay time profile of fungi isolated from

hydrophobins/HYD-LPs play major role in conferring hydrophobicity to spores; secretion of these proteins in fermentation broth during growth of these fungi could

S5sample, e foam half decay time profile of fungi isolated from S7sample, $\mathbf{f}$ foam half decay time profile of fungi isolated from S8sample, $\mathbf{g}$ Comparison of half decay time profile of stably foaming fungal strain

be considered as a foam stability factor. Results obtained in this study suggested that secretion of HYD-LPs in to fermentation broth could be species specific and hence it 
was difficult to establish any relationship in between these two parameters. Expression levels and secretion of hydrophobins Vmh1, Vmh2 and Vmh3 of Pleurotus ostreatus into fermentation medium were found dependent on conditions like specific nutrient availability, culture conditions, and time of cultural growth [45].

Different studies suggested that foam stability of fermentation/culture broth has been used as a promising screening technique for selection of potential hydrophobin/ surface active protein producing fungi. Marine fungi collected nearby Elba Island in the Mediterranean Sea were screened for hydrophobin producer fungi on the basis of ability to produce stable foam in cell free culture broth. Twenty-three fungi out of 100 were selected using this criterion and further evaluated for other biosurfactant properties and resulted in isolation of six different strains producing HYD-LPs [31]. Penicillium oxalicum strain producing gushing inducing surface active protein like hydrophobin was isolated from grape associated fungi using foam fractionation method [5]. Class II hydrophobin FcHyd5p of Fusarium culmorum was expressed in Pichia pastoris and expression was evaluated by inducing foam in fermentation broth. P. pastoris clone secreting FcHyd5p in culture broth resulted in formation of foam stable for $72 \mathrm{~h}[46]$

\subsection{Morphological identification and study of biosurfactant properties of selected fungal strains}

Selected 15 fungal strains were identified by studying morphological characteristics. Identification report suggested that 14 strains were of Aspergillus genera and one species was found close to Penicllium islandicum (Table 1). Table 1 summarizes the biosurfactant activities of all fungal strains. Foam produced by these strains was collected and used for other biosurfactant properties like surface tension reduction, oil displacement assay and emulsification index using foam produced by them. According to studies hydrophobins cover surface of air bubbles formed during foaming, remain entrapped in foam phase of the broth and decrease the surface tension of the broth $[43,47]$. Immediate collection of this foam phase and use of it for evaluation of different biosurfactant characteristics indirectly helped to ensure presence of HYD-LPs in the culture broth. This indirect measure supported to set reduction in surface tension of PDB medium as a key criterion to select fungal strains for isolation and purification of HYD-LPs. The approach of collecting foam and utilizing it for characterization of biosurfactant activities has been reported first time. Total protein content of collected foam was estimated and correlation between protein content and decrease in surface tension was studied. Foam of strains S1-7, S2-8, S2-9, S8-2, S8-5 and S8-6 have shown good concentration of total protein (Table1). Out of these strains only $A$. fumigatus (S1-7) and $A$. flavus (S8-6), have effectively lowered the surface tension of PDB by $22 \mathrm{mN} / \mathrm{m}$ and $21.42 \mathrm{mN} / \mathrm{m}$ respectively. It indicated that high concentration of protein in foam did not ensure presence of hydrophobins/ HYD-LPs. The third promising candidate of the study was Penicillium species close to $P$. islandicum (S7-5), which has decreased surface tension of PDB medium by $27.868 \mathrm{mN} / \mathrm{m}$ but total protein content of the foam was less $(0.7235 \mathrm{mg} / \mathrm{ml})$. Except these strains all the other foam producing strains did not show correlation in total protein content, surface tension reduction and emulsification index.

It was studied and explained for different biosurfactants that chemical composition of biosurfactants and bioemulsifiers is different, so their properties are different. Biosurfactants reduce surface tension while bioemulsifiers only stabilize the emulsions [48]. Biosurfactants form stable foam/emulsions by lowering surface tension or interfacial tension of immiscible phases. Bioemulsifier forms stable emulsion by binding water insoluble substrates together without playing role in reduction of surface tension [48]. Hydrophobins/HYD-LPs like biosurfactants stabilize foam and emulsions by both the mechanism i.e. they decrease the surface tension between two immiscible phases as well as bind to insoluble substrates by coating them quickly. It results in buffer against coalescence of bubbles formed in foam and escaping of insoluble substrates from emulsion [43]. In consideration with dual nature of hydrophobins; interest of the study was inclined to select strain exhibiting both the properties i.e. reducing surface tension and emulsification. The mechanism of lowering of surface tension, foam stability and stable emulsion formation was collectively exhibited by fermentation broth of strains S7-5 (Penicillium species close to P. islandicum), S1-7 (A. fumigatus) and S8-6 (A. flavus). Literature study suggested that for past many years Aspergillus species have been thoroughly studied for isolation of hydrophobins. Hydrophobin extraction is successfully carried out from various Aspergillus strains including $A$. fumigatus and $A$. flavus. Rod $A$ and Rod $B$ hydrophobins have been isolated from $A$. fumigatus and recently Rod $A$ has been isolated from $A$. flavus [49-51]. In comparison to this; study on isolation of hydrophobin/HYD-LP is very limited to few strains of Penicillium though the species is well reported for expressing genes of hydrophobins at different developmental stages of the fungi. Few attempts were made for isolation of hydrophobins from $P$. oxalicum and $P$. chrysogenum $[5,5]$. In both the studies surface active proteins were isolated similar to hydrophobins but these proteins are not belonging to family of hydrophobins. In consideration 
with these literature reports S7-5 (Penicillium species close to $P$. islandicum like strain) was selected for extraction of HYD-LPs from spores, mycelium and foam. Hydrophobin HFB II isolated from Trichoderma reesei has illustrated same mechanism of forming stable emulsions with foam stability for longer time (about 45 days) [21]. This protein is well-studied as a model system for studying applications of hydrophobins as food foams [43].

\subsection{Isolation, purification and analysis of surface active HYD-LPs}

In consideration with presence of hydrophobins on cell surface of fungi, attempts were made to isolate hydrophobins/HYD-LPs from spores, Mycelia and secreted proteins from fermentation broths using method described by Wessels et al. [27] and de Vries et al. [28] for class I proteins. To isolate class II HYD-LPs method described by Carpenter et al. [30] and Cicatiellao et al. [31] was followed. To isolate class I HYD/ HYD-LPs from spores strain S7-5 was grown on PDA plates. Spores were collected from plates and treated with hot SDS. After removing SDS-soluble proteins spores were treated with TFA to dissociate the aggregates of SDSinsoluble proteins present in wall of spores and these aggregates were dissolved in TFA. TFA was removed by air drying and samples were dissolved in $100 \mathrm{mM} \mathrm{Tri-HCl}$ for further analysis.

To isolate class I HYD/HYD-LPs from mycelia, strain S7-5 (Penicillium species close to Penicillium species close to $P$. islandicum) was grown in PDB medium for 5 days. Mycelia were separated from fermentation broth by filtration. Mycelia were treated with hot SDS to remove SDS soluble proteins. Remaining SDS-insoluble HYD/HYD-LPs were further purified by treating with TFA. Property of HYD/ HYD-LPs to aggregate at air-water interface was exploited during isolation of these proteins by foaming the fermentation broth. Foam protein was collected in pellet by centrifugation. This foam pellet contained HYD-LPs with some impurities was treated with TFA to dissolve the protein and separated it from other unwanted biomolecules. TFA dissolved protein was air dried and redissolved in $100 \mathrm{mM}$ Tris $\mathrm{HCl}$.

Attempts made to isolate class II HYD-LPs by treating collected mycelia, spores and foam pellet by $60 \%$ ethanol were not successful. Negligible amount of proteins were isolated and clear bands of proteins were not observed after analyzing on SDS-PAGE.

Class I HYD-LPs were successfully isolated only from spores and fermentation broth of S7-5 (Penicillium species close to Penicillium species close to P. islandicum). Concentration of proteins isolated from fermentation broth and spores was $1.075 \mathrm{mg} / \mathrm{ml}$ and $0.51 \mathrm{mg} / \mathrm{ml}$ respectively with very less volume of $1 \mathrm{ml}$. Isolated proteins were analyzed

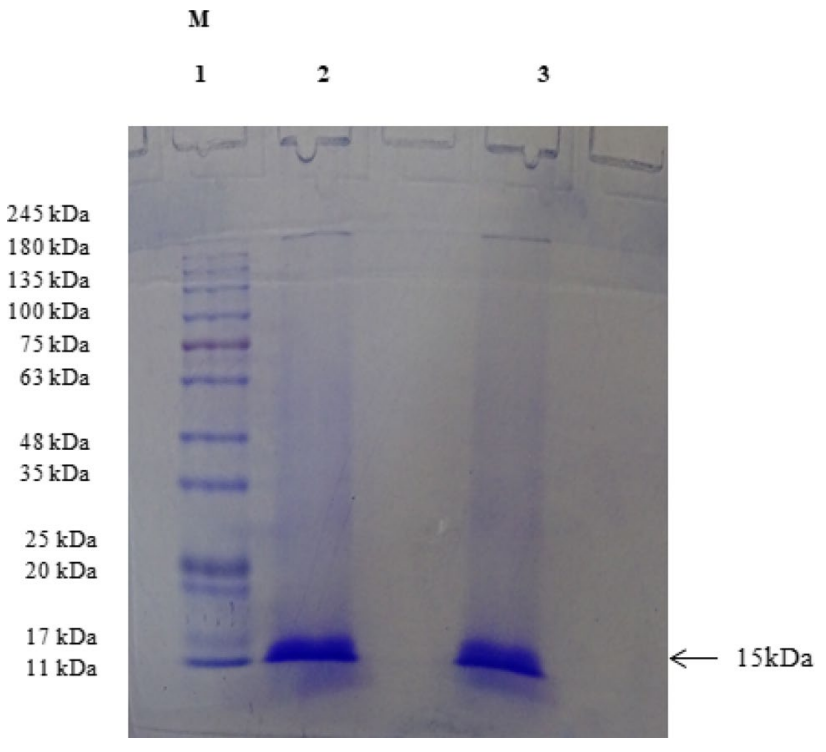

Fig. 3 HYD-LPs isolated from of Penicillium species close to P.islandicum (S7-5). 1-M-molecular weight marker, 2-HYD-LP isolated from S7-5 spores, 3-HYD-LP isolated from fermentation broth

using SDS-PAGE (Fig. 3). Lane 1 represents molecular weight markers ranging from 11 to $245 \mathrm{kDa}$. Extracted HYD-LP from spores was loaded in lane 2. Single prominent protein band was observed just below $17 \mathrm{kDa}$ protein band of the marker. This protein was approximately of $15 \mathrm{kDa}$ like reported low molecular weight hydrophobins isolated from different fungal strains. HYD-LP isolated from fermentation broth was presented in lane 3 of Fig. 3. This protein was also of same molecular weight ( $15 \mathrm{kDa})$ like HYD-LP isolated from spores of the strain S7-5.

\subsubsection{Analysis of HYD-LP using RP-HPLC}

Isolated HYD-LP was analyzed using reverse phase high performance liquid chromatography (RP-HPLC). Purified HYD-LP was dissolved in solvent A (0.1\% TFA in water) and loaded on to $C 18$ column for protein analysis. HPLC analysis method used for analysis of HYDPt- 1 isolated from Pisolithus tinctorius was followed here [33]. Acetonitrile (ACN) gradient was established in column by running solvent B for $40 \mathrm{~min}$. 0-40\% ACN gradient was developed by running solvent $B$ for first $15 \mathrm{~min}$. The next gradient of $40-80 \%$ was achieved in next $20 \mathrm{~min}$. Last $5 \mathrm{~min}$ were used to attain peak in ACN concentration of $90 \%$ and quickly returned to $0 \%$. Analysis was carried out at wavelength of $214 \mathrm{~nm}$. Chromatogram obtained is presented in Fig. 4. Out of three peaks observed in figure, first peak was attributed to solvent obtained at zero minute retention time (RT). This was verified by running the solvent alone in HPLC system. Second peak was obtained at $4 \mathrm{~min}$ and third peak at $18 \mathrm{~min}$ at $46 \%$ of acetonitrile. During the developmental 


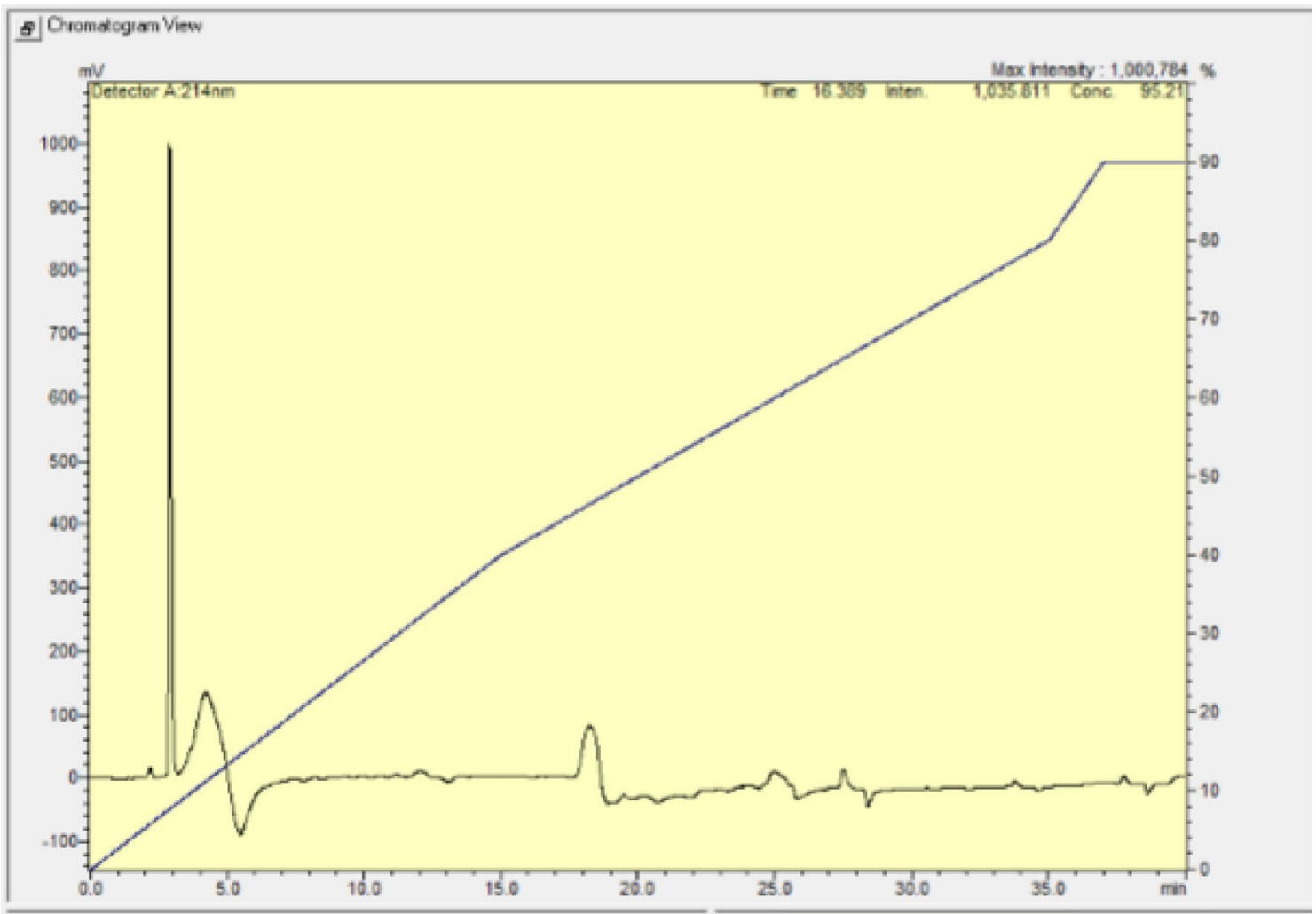

Fig. 4 RP-HPLC analysis of HYD-LP

phase of acetonitrile gradient peak of protein eluted at 18 min between $40-50 \%$ of ACN concentration was of interest for our study.

In literature HPLC has been used to purify the protein and evaluate hydrophobic/amphipathic nature of the protein by eluting it using gradient of acetonitrile within the range of wavelength of $214-220 \mathrm{~nm}$ on either C18 or C4 column [29, 33,53,54]. It was interesting to find that almost all HYD/HYD-LP isolated from various fungal sources were eluting at gradient of $30-50 \%$ of acetonitrile. This elution confirmed the relative hydrophobicity of monomeric form of isolated hydrophobins from various fungal strains $[33,53,54]$. All the RP-HPLC conditions followed for analysis of HYD-LP were similar to HYDPt-1; hence results obtained in this study were directly compared with RPHPLC analysis of HYDPt-1 [33]. Peak obtained in Fig. 4 at 18 min retention time (RT) and $46 \%$ acetonitrile concentration could be compared with peak corresponding to HYDPt- 1 eluted at $43 \%$ of acetonitrile gradient with (RT) in between 18-20 min. Comparison of these two chromatograms clearly indicated that RT and \% acetonitrile gradient of both the proteins was similar suggesting similarity in their hydrophobic/amphipathic nature. Since HYDPt- 1 is completely characterized class-I hydrophobin found in cell walls of $P$. tinctorius hyphae; this RP-HPLC analysis helped to partially characterize isolated low molecular weight protein $(15 \mathrm{kDa})$ in to HYD-LP.

These results confirmed isolation of low molecular weight, SDS insoluble class I HYD-LP from Penicillium species close to $P$. islandicum (S7-5). These proteins can be considered as putative hydrophobin like proteins (HYD-LPs), which corresponds usually to average molecular weight range of $7-23 \mathrm{kDa}[28,29,33,53,54]$.

\subsection{Contact angle measurements}

a) Contact Angle determination of Proteins:

Amphipathic nature of purified SDS-insoluble proteins was studied using contact angle (CA) measurement. Contact angles of purified proteins were compared with CA of water as a negative control and of SDS as a positive control on Teflon surface. Table 2 summaries contact angle measurement results of proteins extracted from spores and fermentation broth of S7-5. Due to highly hydrophobic nature of Teflon water has made largest contact angle with it. SDS being an anionic surfactant has made lowest contact angle with the same surface. Protein extracted from spores and fermentation broth has shown contact angles in between these two 
Table 2 Contact angles made by purified HYD-LPs with Teflon surface

\begin{tabular}{llll}
\hline S. no & Protein samples isolated from S7-5 & $\begin{array}{l}\text { Average concentration of } \\
\text { extracted protein }(\mathrm{mg} / \mathrm{mL})\end{array}$ & Contact angles \\
\hline 1 & Distilled water & - & $134.06^{\circ} \pm 0.03$ \\
2 & $2 \%$ SDS & - & $71.26^{\circ} \pm 0.10$ \\
3 & HYD-LP (spores) & $50 \mu \mathrm{g} / \mathrm{ml}$ & $81.587^{\circ} \pm 0.95$ \\
4 & HYD-LP (fermentation broth) & $50 \mu \mathrm{g} / \mathrm{ml}$ & $\begin{array}{c}\text { Flat shape drop unable to } \\
\text { measure contact angle } \\
\end{array}$ \\
& & $(\theta \approx 0)$ \\
\hline
\end{tabular}

controls. Proteins samples of concentration of $50 \mu \mathrm{g} /$ $\mathrm{ml}$ were used to load on to Teflon surface. Lowered CA than water, indicate hydrophobic nature of extracted proteins like hydrophobins. Spore protein has shown lowered Contact angle of $81.587^{\circ}$ which is lowered by $52.478^{\circ}$ than water. Interestingly foam protein samples failed to make drop on Teflon surface and has given flat shape of $10 \mu \mathrm{l}$ protein sample. Contact angle measurement of the shape was not possible $(\theta \approx 0)$. These results indicated that proteins extracted from spores and foam were amphiphilic in nature. This property of lowering CA was observed in almost all isolated hydrophobins. To mention a few, hydrophobins isolated from Paecilomyces farinosus $\mathrm{PfaH} 1$ and $\mathrm{PfaH} 2$ has made the contact angle of $118^{\circ}$ with Teflon which was lowered by $3.9^{\circ}$ than water $\left(121.9^{\circ}\right)$ [55]. Hydrophobins of Metarhizium anisopliae have made contact angles of $57.06^{\circ}$ and $58.43^{\circ}$ with Teflon, these CA were too small compared to CA made by water with Teflon surface of about $121^{\circ}$ [34].

\section{b) Wetting ability Determination of isolated Surface} active proteins:

The ability of proteins extracted from spores and foam of S7-5 (Penicillium species close to P. islandicum) species, to change wettability of protein treated Teflon surface was studied by analyzing water contact angle measurements. Results are summarized in Table 3. Foam proteins changed wettability of Teflon surface by decreasing CA of water by $37.62 \%$. Proteins extracted from spores decreased CA of water by $21.63 \%$. Both these proteins have made stable layers, resistant to $2 \%$ hot SDS, confirmed the noncovalent interactions between monomers at solid-air interface [21]. Surface active proteins like Class I hydrophobins form rodlet layer at solid-air interface and help to increase hydrophilicity of Teflon by decreasing contact angle of water. Class II hydrophobins form aggregates devoid of rodlet structure and change the wettability of the surface [56]. Dwindling of CA is the clear indication of amphipathic nature of extracted protein from spores and fermentation broth of $P$. islandicum close spp. (S7-5). Hydrophobins extracted from different species have been analyzed for changing surface wettability and found to
Table 3 Contact angle measurements of water on teflon surface coated with HYD-LP isolated

\begin{tabular}{llll}
\hline $\begin{array}{l}\text { S. no } \\
\text { from S7-5 }\end{array}$ & $\begin{array}{l}\text { Protein sample isolated } \\
\text { fontact angle }\end{array}$ & $\begin{array}{l}\text { \% Decrease in } \\
\text { CA of DI water }\end{array}$ \\
\hline & Control & $132.831^{\circ} \pm 0.87$ & - \\
1 & $\begin{array}{c}\text { HYD-LP (fermentation } \\
\text { broth) }\end{array}$ & $82.965^{\circ} \pm 2.26$ & $37.62 \% \pm 1.34$ \\
2 & HYD-LP (spores) & $104.094^{\circ} \pm 0.16$ & $21.63 \% \pm 0.63$ \\
\hline
\end{tabular}

decrease water contact angle from $36^{\circ}$ for SC3 isolated from S. commune to $91^{\circ}$ for recombinant RODB from $A$. fumigatus $[57,58]$. This study helped to partially characterize this protein as hydrophobin like protein exhibiting hydrophobic properties.

\section{Conclusions}

In current study, Biosurfactant properties of fungi isolated from malted barley waste samples were reported first time. Screening of these fungi was resulted in 15 isolates out of 50, with ability to produce stable foams up to $8 \mathrm{~h}$ and 10 were found with more foam half decay time than SDS. All foamable strains reduced surface tension of PDB in the range of $10-20 \mathrm{mN} / \mathrm{m}$. These fungal isolates also displayed good oil spreading activity and emulsification activity. Strain S7-5 which has been morphologically identified as Penicillium species close to P. islandicum was found to be most sufficient in lowering the surface tension up to $31.046 \mathrm{mN} / \mathrm{m}$. Low molecular weight SDSinsoluble HYD-LP of approximately $15 \mathrm{kDa}$ was isolated from spore walls and foam of S7-5 (Penicillium species close to $P$. islandicum) strain using Trifluroacetic acid (TFA). Hydrophobic nature of this protein was confirmed by RP-HPLC analysis. This protein has exhibited amphipathic nature like hydrophobins on hydrophobic Teflon surface at air-solid interface and made low contact angles than water. It has also reduced hydrophobicity of Teflon by decreasing contact angle of water by $37.62 \%$ for foam proteins and by $21.63 \%$ for spore wall protein. The work will be continued for identification of isolated 
HYD-LP and development of high yield bioprocess for production of this protein.

Acknowledgement We would like to thank Department of Biotechnology, Sinhgad College of Engineering for providing laboratory facilities. We would also like to thank National Fungal Culture Collection of India-Agharkar Research Institute (NFCCI-ARI), Pune Maharashtra India for their support in Morphological Identification of Fungal Strains. We would also like to thank Venture center for their analytical support. HPLC Analysis was performed by Ms. Edna at the DST/DBT-BIRAC supported Venture Center, at CSIR-NCL, Pune, India.

Funding This research did not receive any specific grant from funding agencies in the public, commercial, or not-for-profit sectors.

\section{Compliance with ethical standards}

Conflict of interest The authors declare that they have no conflict of interest.

\section{References}

1. Schwarz PB, Beattle S, Casper HH (1996) Relationship between Fusarium infestation of barley and the gushing potential of malt. J Inst Brew 102:93-96. https://doi.org/10.1002/j.2050-0416.1996. tb00899.x

2. Sarlin T, Nakari-Setälä T, Linder $M$, Penttilä $M$, Haikara A (2005) Fungal hydrophobins as predictors of the gushing activity of malt. J Inst Brew 111(2):105-111. https://doi. org/10.1002/j.2050-0416.2005.tb00655.x

3. Sarlin T, Vilopa A, Kotaviita E, Olkku J, Haikara A (2007) Fungal hydrophobins in the barley-to-beer chain. J Inst Brew 113(2):147-153. https://doi.org/10.1002/j.2050-0416.2007. tb00271.x

4. Amaha M, Kitabatake K, Nakagava A, Yoshida J, Harada T (1973) Gushing inducers produced by some moulds strains. In: Proceedings of the European Brewery convention congress, Salzburg. Elsevier, Amsterdam, pp. 381-398

5. Vogt El, Kupfer VM, Vogel RF, Niessen L (2017) Evidence of gushing induction by Penicillium oxalicum proteins. J Appl Microbiol 122(2):708-718. https://doi.org/10.1111/jam.13366

6. Wösten HA, van Wetter MA, Lugones LG, van der Mei HC, Busscher HJ, Wessels JG (1999) How a fungus escapes the water to grow into the air. Curr Biol 9(2):85-88. https://doi. org/10.1016/S0960-9822(99)80019-0

7. Wösten HA, Schuren FH, Wessels JG (1994) Interfacial self-assembly of a hydrophobin into an amphipathic protein membrane mediates fungal attachment to hydrophobic surfaces. EMBO J 13:5848-5854. https://doi.org/10.1002/j.1460-2075.1994.tb069 29.x

8. Aimanianda V, Bayry J, Bozza S, Kniemeyer O, Perruccio K, Elluru SR, Clavaud C, Paris S, Brakhage AA, Kaveri SV, Romani L, Latgé JP (2009) Surface hydrophobin prevents immune recognition of airborne fungal spores. Nature 460(7259):1117-1121. https ://doi.org/10.1038/nature08264

9. Wösten HA, Scholtmeijer K (2015) Applications of hydrophobins: current state and perspectives. Appl Microbiol Biotechnol 99(4):1587-1597. https://doi.org/10.1007/s00253-014-6319-x

10. Tymiński $Ł$, Znajewska Z, Dąbrowska GB (2018) Characteristic and functions of hydrophobins and their use in manifold industries. Post Mikrobiol 57(4):374-384. https://doi. org/10.21307/PM-2018.57.4.374

11. Segers GC, Hamada W, Oliver P, Spanu PD (1999) Isolation and characterization of five different hydrophobin encoding CDNAs from the fungal tomato pathogen Cladosporium fulvum. Mol Gen Genet 261:644-652. https://doi.org/10.1007/s004380050 007

12. Tagu D, Martin F (1996) Molecular analysis of cell wall proteins expressed during the early steps of ectomycorrhiza development. New Phytol 133:73-85. https://doi. org/10.1111/j.1469-8137.1996.tb04343.x

13. MartInez AT, Camarero S, GuiMn F, Gutibrrez A, Mufioz C, Varela E, Martinez MJ, Barrasal M, Ruel K, Pelayo JM (1994) Progress in biopulping of nonwoody materials: chemical, enzymatic and ultrastructural aspects of wheat straw delignification with ligninolytic fungi from the genus Pleurotus. FEMS Microbiol Rev 13:265-274. https://doi.org/10.1111/j.1574-6976.1994.tb000 $47 . x$

14. Zhang RY, Hu D, Gu GJ, Zhang JX, Goodwin PH, Hu QX (2015) Purification of a novel Hydrophobin PN1 involved in antibacterial activity from an edible mushroom Pleurotus nebrodensis. Eur J Plant Pathol 143(4):823-831. https://doi.org/10.1007/s1065 8-015-0734-4

15. Vigueras G, Shirai K, Martins D, Franco TT, Fleuri LF, Revah S (2008) Toluene gas phase biofiltration by Paecilomyces lilacinus and isolation and identification of a Hydrophobin protein produced thereof. Appl Microbiol Biotechnol 80:147-154. https:// doi.org/10.1007/s00253-008-1490-6

16. Gray NF (1984) Ecology of nematophagous fungi: comparison of the soil sprinkling method with the baermann funnel technique in the isolation of endoparasites. Soil Biol Biochem 16:81-83. https://doi.org/10.1016/0038-0717(84)90131-7

17. Mozes N, Rouxhet PG (1987) Methods for measuring hydrophobicity of microorganisms. J Microbiol Methods 6:99-112. https ://doi.org/10.1016/0167-7012(87)90058-3

18. Amaral MH, das Neves J, Angela Z, Oliveira AZ, Bahia MF (2008) Foamability of detergent solutions prepared with different types of surfactants and waters. J Surfactant Deterg 11:275-278. https ://doi.org/10.1007/s11743-008-1088-0

19. Osei-Bonsua K, Shokria N, Grassiab P (2015) Foam stability in the presence and absence of hydrocarbons: from bubble- to bulkscale. Colloids Surf A 481:514-526. https://doi.org/10.1016/j. colsurfa.2015.06.023

20. Bradford MM (1976) A rapid and sensitive method for the quantitation of microgram quantities of protein utilizing the principle of protein-dye binding. Anal Biochem 72:248-254. https://doi. org/10.1016/0003-2697(76)90527-3

21. Tchuenbou-Magaia FL, Norton IT, Cox PW (2009) Hydrophobins stabilized air-filled emulsions for the food industry. Food Hydrocoll 23:1877-1885. https://doi.org/10.1016/j.foodh yd.2009.03.005

22. Cooper D, Goldenberg B (1987) Surface-active agents from two Bacillus species. Appl Environ Microbiol 53(2):224-229 (PMID: 16347271)

23. Ma MA, Shan LJ, Wang HJ, Du ZP, Xie BJ (2008) Partial characterization of a hydrophobin protein Po.HYD1 purified from the oyster mushroom Pleurotus ostreatus. World J Microbial Biotechnol 24:501-507. https://doi.org/10.1007/s11274-007-9500-x

24. Niu B, Wang D, Yang Y, Xu H, Qiao M (2012) Heterologous expression and characterization of the Hydrophobin HFB I in Pichia pastoris and evaluation of its contribution to the food industry. Amino Acids 43:763-771. https://doi.org/10.1007/s0072 6-011-1126-5

25. Morikova M, Hirata Y, Imanaka T (2000) A study on the structure-function relationship of the lipopeptide biosurfactants. 
Bio Chim Biophys Acta 1488:211-218. https://doi.org/10.1016/ S1388-1981(00)00124-4

26. Youssef NH, Duncan KE, Nagle DP, Savager KN, Knapp RM, Mclnerney MJ (2004) Comparison of methods to detect biosurfactant production by diverse microorganisms. J Microbiol Methods 56:339-346. https://doi.org/10.1016/j.mimet.2003.11.001

27. Wessels JGH, Vries OMH, Àsgeirsdottir SA, Schuren FHJ (1991) Hydrophobin genes involved in formation of aerial hyphae and fruit bodies in Schizophyllum. Plant Cell 3:793-799. https://doi. org/10.2307/3869273

28. de Vries OMH, Fekkes MP, WÖsten HAB, Wessels JGH, (1993) Insoluble hydrophobin complexes in the walls of Schizophyllum commune and other filamentous fungi. Arch Microbiol 159:330-335. https://doi.org/10.1007/BF00290915

29. Longobardi S, Picone D, Ercole C, Spadaccini R, De Stefano L, Rea I, Giardina P (2012) Environmental conditions modulate the switch among different states of the hydrophobin $\mathrm{Vmh} 2$ from Pleurotus ostreatus. Bio Macromol 13:743-750. https://doi.org/10.1021/ bm201663f

30. Carpenter CE, Mueller RJ, Kazmierczak P, Zhang L, Villalon DK, van Alfen NK (1992) Effect of a virus on accumulation of a tissuespecific cell-surface protein of the fungus Cryphonectria (Endothia) parasitica. Mol Plant Microbe Interact 5:55-61. https://doi. org/10.1094/mpmi-5-055

31. Cicatiello P, Gravagnuolo AM, GiorgioGnavi G, Varese GC, Giardina P (2016) Marine fungi as source of new hydrophobins. Int J Biol Macromol 92:1229-1233. https://doi.org/10.1016/j.ijbio mac.2016.08.037

32. Laemmli UK (1970) Cleavage of structural proteins during the assembly of the head of bacteriophage T4. Nature 227:680-685. https://doi.org/10.1038/227680a0

33. Tagu D, Bellis RD, Balestrini R, De Vries OMH, Piccoli G, Stocchi V, Bonfante P, Martin F (2001) Immunolocalization of hydrophobin HYDPt-1 from the ectomycorrhizal basidiomycetes Pisolithus tinctorius during colonization of Eucalyptus globulus roots. New Phytol 149:127-135. https://doi.org/10.1046/j.1469-8137.2001.00009.x

34. Kiong DSB, Bong CFJ, King PJH (2015) Isolation and Physical Characterization hydrophobin-like proteins (HLP) from Aerial Conidia of Metarhizium Anisopliae Var. Anisopliae. Am J Biochem Biotechnol 11(2):66-72. https://doi.org/10.3844/ajbbsp.2015.66.72

35. Stalder AR, Melchior T, Muller M, Sage D, Blu T et al (2010) Lowbond axisymmetric drop shape analysis for surface tension and contact angle measurements of sessile drops. Coll Surf 364:72-81. https://doi.org/10.1016/j.colsurfa.2010.04.040

36. Williams DL, Kuhn AT, Amann MA, Hausinger MD, Konarik MM et al (2010) Computerised measurement of contact angles. Galvanotechnik 10:1-11

37. Ball SR, Kwan AH, Sunde M (2019) Hydrophobin rodlets on the fungal cell wall. Current topics in microbiology and immunology. Springer, Berlin, pp 1-23. https://doi.org/10.1007/82_2019_186

38. Linder MB, Szilvay GR, Nakari-Setälä T, Penttilä ME (2005) Hydrophobin: the protein amphiphiles of filamentous fungi. FEMS Microbiol 29:877-896. https://doi.org/10.1016/j.femsr e.2005.01.004

39. Wosten HAB (2001) Hydrophobins: multipurpose proteins. Annu Rev Microbiol 55:625-646. https://doi.org/10.1146/annurev.micro .55 .1 .625

40. Dimitrova LM, Petkov PV, Kralchevsky PA, Stoyanov SD, Pelanb EG (2017) Production and characterization of stable foams with fine bubbles from solutions of hydrophobin HFBII and its mixtures with other proteins. Colloids Surf A 521:92-104. https://doi. org/10.1016/j.colsurfa.2016.06.018

41. Cox AR, Aldred DL, Russell AB (2009) Exceptional stability of food foams using class II hydrophobin HFBll. Food Hydrocoll 23(2):366376. https://doi.org/10.1016/j.foodhyd.2008.03.001
42. Lohrasbi-Nejad A, Torkzadeh-Mahani M, Hosseinkhani S (2016) Heterologous expression of a hydrophobin HFB1 and evaluation of its contribution to producing stable foam. Protein Expr Purif 118:25-30. https://doi.org/10.1016/j.pep.2015.09.025

43. Green AJ, Littlejohn KA, Hooley P, Cox PW (2013) Formation and stability of food foams and aerated emulsions: hydrophobins as novel functional ingredients. Curr Opin Colloid Interface Sci 18(4):292-301. https://doi.org/10.1016/j.cocis.2013.04.008

44. Bailey MJ, Askolin S, Hörhammer N, Tenkanen M, Linder M, NakariSetälä PT (2002) Process technological effects of deletion and amplification of hydrophobins I and II in transformants of Trichoderma reesei. Appl Microbiol Biotechnol 58:721-727. https://doi. org/10.1007/s00253-002-0966-z

45. Peñas MM, Rust B, Larraya LM, Ramírez L, Pisabarro AG (2002) Differentially regulated vegetative mycelium specific hydrophobins of the edible basidiomycetes Pleurotus ostreatus. Appl Environ Microbiol 68:3891-3898. https://doi.org/10.1128/ AEM.68.8.3891-3898.2002

46. Stübner M, Lutterschmid G, Vogel RF (2010) Niessen L (2010) Heterologous expression of the hydrophobin FcHyd5p from Fusarium culmorum in Pichia pastoris and evaluation of its surface activity and contribution to gushing of carbonated beverages. Int J Food Microbiol 141:110-115. https://doi.org/10.1016/j.ijfoodmicr 0.2010 .03 .003

47. Linder MB (2009) Hydrophobins: proteins that self assemble at interfaces. Curr Opin Colloid Interface Sci 14(5):356-363. https:// doi.org/10.1016/j.cocis.2009.04.001

48. Uzoigwe C, Burgess JG, Ennis CJ, Rahman PKSM (2015) Bioemulsifiers are not biosurfactants and require different screening approaches. Front Microbiol 6:1-6. https://doi.org/10.3389/fmicb 2015.00245

49. Dynesen J, Nielsen J (2003) Surface hydrophobicity of Aspergillus nidulans conidiospores and its role in pellet formation. Biotechnol Prog 19:1049-1052. https://doi.org/10.1021/bp0340032

50. Paris S, Debeaupuis JP, Crameri R, Carey M, Charlès F, Prévost MC, Schmitt C, Philippe B, Latgé JP (2003) Conidial hydrophobins of Aspergillus fumigatus. Appl Environ Microbiol 69(3):1581-1588. https://doi.org/10.1128/AEM.69.3.1581-1588.2003

51. Mohammed MRS, Balamurugan $M$, Amrathlald RS, Kannan $P$, Jayapal JM, Namperumalsamy VP, Prajna L, Kuppamuthu D (2019) Identification of the proteoforms of surface localized Rod A of Aspergillus flavus and determination of the mechanism of proteoform generation. J Proteom 193:62-70. https://doi.org/10.1016/j. jprot.2018.12.016

52. Cicatiello P, Stanzione I, Dardano P et al (2019) Characterization of a surface-active protein extracted from a marine strain of Penicillium chrysogenum. Int J Mol Sci 20(13):3242. https://doi. org/10.3390/ijms20133242

53. Wang Z, Feng S, Huang Y, Li S, Xu H, Zhang X, Bai Y, Qiao M (2010) Expression and characterization of Grifola frondosa hydrophobin in Pichia pastoris. Protein Expr Purif 72:19-25. https://doi. org/10.1016/j.pep.2010.03.017

54. Rocha-Pino Z, Vigueras G, Sepúlveda-Sánchez JD, HernándezGuerrero M, Campos-Terán J, Fernández FJ, Shiral K (2015) The hydrophobicity of the support in solid state culture affected the production of hydrophobins from Lecanicillium lecanii. Process Biochem 50:14-19. https://doi.org/10.1016/j.procbio.2014.10.021

55. Zelena K, Takenberg M, Lunkenbein S, Woche SK, Nimtz M, Berger RG (2013) PfaH2: A novel hydrophobin from the ascomycete Paecilomyces farinosus. Biotechnol Appl Biochem. https://doi. org/10.1002/bab.1077

56. Sunde M, Kwan AHY, Templeton MD, Beever RE, Mackay JP (2008) Structural analysis of hydrophobins. Micron 39(7):773-778. https ://doi.org/10.1016/j.micron.2007.08.003

57. Pedersen MH, Borodina I, Moresco JL, Svendsen WE, Frisvad JC, Ib S (2011) High-yield production of hydrophobins RodA and 
RodB from Aspergillus fumigatus in Pichia pastoris. Biotechnol Prod Process Eng 90:1923-1932. https://doi.org/10.1007/s0025 3-011-3235-1

58. Janssen $\mathrm{MI}$, van Leeuwen $\mathrm{MBM}$, van Kooten $\mathrm{TG}$, de VriesJ $\mathrm{DL}$, Wo" sten HAB, (2004) Promotion of fibroblast activity by coating with hydrophobin in the $\beta$-sheet end state. Biomaterials 25:27312739. https://doi.org/10.1016/j.biomaterials.2003.09.060
Publisher's Note Springer Nature remains neutral with regard to jurisdictional claims in published maps and institutional affiliations.

\section{SN Applied Sciences}

a SPRINGer NATURE journal 